\title{
Response of Fiber Quality to Temperature Degree and Lint Cotton Grade in Two Long Staple Varieties
}

\author{
Ibrahim, A. E. Ibrahim ${ }^{1}$, and Ali. A. A. El-Banna ${ }^{1}$
}

\begin{abstract}
This study was carried out at Plant Production Department, Faculty of Agriculture (Saba Basha), Alexandria University, Egypt, during 2016/2017 season to investigate the effect of conditioning temperature degrees and lint grades on cotton fiber properties of two long staple varieties. Three lint cotton grades; namely, Good to Fully Good (G/FG), Good (G) and Fully Good Fair to Good (FGF/G) belong to Egyptian long staple cotton varieties; Giza 86 and Giza 94 were used. Four conditioning temperature degrees were used; i.e., $21^{\circ} \mathrm{C}, 23^{\circ} \mathrm{C}, 25^{\circ} \mathrm{C}$ and $27^{\circ} \mathrm{C}$. Results showed that Good to Fully Good (G/FG) cotton grade surpassed the other two cotton grades and gave the highest mean values of spinning consistency index (SCI), length uniformity index (\%), fiber bundle strength, maturity index $(\%)$, micronaire reading and fiber reflectance degree (Rd \%). Conversely, this grade registered the lowest values for short fiber index $(\%)$, yellowness degree $(+b)$, trash count and trash area $(\%)$. Upper half mean length, spinning consistency index, fiber bundle strength, fiber elongation (\%) and micronaire reading were the highest with temperature degree $21^{\circ} \mathrm{C}$, but this temperature degree produced the lowest mean value of short fiber index. The highest mean values for length uniformity index, short fiber index, fiber bundle strength, maturity index and micronaire reading were registered for Giza 86 cotton variety as compared to Giza 94 cotton variety. Best fiber quality properties over all studied cotton varieties and grades were achieved at $21^{\circ} \mathrm{C}$ conditioning temperature.
\end{abstract}

Key words: Cotton, Conditioning, Fiber, Grade, Temperature degree, Variety

\section{INTRODUCTION}

Control of temperature degree and relative humidity are very important during fiber and textile processing to aid in optimizing cotton fiber performance.

Cotton moisture content and conditioning methodology affect the strength, so, the samples moisture content must be in equilibrium with the approved atmospheric conditions before and during testing. The interaction between genetic (Richard et al. 2006), and environmental conditions (Yeates et al. 2010) results the cotton fiber quality.

Variations between cotton cultivars and their fiber properties make the assessment of basic fiber characters and quality classification is complex and that cause an important problem for the traders, spinners and agricultural researchers who want to improve the cotton yield features. For a better, more comprehensive and objective fiber assessment, a lot of efforts have been and still done to improve the used measurements methods or to develop new ones.

Because of increasing the competition of cotton industry with the industry of man-made fibers, the advancement in measuring systems and gathered knowledge applications is still important. There are a lot of factors which affect the cotton quality like cultivation harvesting and ginning conditions (trash content, seed coat fragment content and nep content), intrinsic parameters (maturity, stickiness, color) and physicalmechanical parameters which can be measured by modern instruments.

Atmosphere has a great effect on the textile properties as moisture content, so the designation of the standard atmosphere conditions is very important which should be $65 \%$ relative humidity (RH) and $20{ }^{\circ} \mathrm{C}$ a temperature degree, but they can be little changed in the practical use to be $65 \% \pm 2 \% \mathrm{RH}$ and $20^{\circ} \mathrm{C} \pm 2{ }^{\circ} \mathrm{C}$. In tropical and subtropical countries, a temperature condition degree of $27^{\circ} \mathrm{C} \pm 2{ }^{\circ} \mathrm{C}$ may be used, (https://nptel.ac.in/courses/116102029/23)

Although the controlled atmospheric conditions, it is not desirable to start very soon in testing the samples in the laboratory, but it should take enough time to reach equilibrium conditions. In addition, for cotton fiber, the standard atmospheric conditions should be $21 \pm 1^{\circ} \mathrm{C}$ and $65 \pm 2 \%$ relative humidity, but for yarns and fabrics testing, a relative humidity is $65 \pm 5 \%$. Laboratories utilize ISO $139: 2005$ are $21 \pm 1^{\circ} \mathrm{C}$ and $65 \pm 4 \%$ relative humidity. Depending on the moisture content, cotton fiber strength and elongation measurements are changed more than other physical measurements (ASTM, 2015). During the classing season and testing time, the laboratory must be conditioned continuously for 24 hours a day, 7 days a week and if there is any exceeding for these conditions, the instrument testing must be stopped, and the conditions must be set up again. All these deviations and corrections must be recorded.

So, it is necessary to monitor the temperature and humidity continuously with independent sensors. In the present study, we are trying to evaluate the effect of conditioning temperature degree and lint cotton grade on cotton fiber properties for long staple cotton varieties.

\footnotetext{
1. Associate Prof., Plant Production Dept. Faculty of Agric.

(Saba Basha), AlexandriaUniversity, Egypt.

E-mail: dribrahimabbas@yahoo.com

Received September 06, 2018, Accepted September 30, 2018
} 


\section{MATERIALS AND METHODS}

This study was carried out at Plant Production Department, Faculty of Agriculture (Saba Basha), Alexandria University, Egypt, during 2016/2017 season by using three lint cotton grades namely: Good to Fully Good (G/FG), Good (G) and Fully Good Fair to Good (FGF/G) belong to two commercial Egyptian long staples (1 1/4 -1 3/8 inch) cotton varieties; i.e., Giza 86 and Giza 94. A lint cotton sample of 800 grams was drawn from each cotton grade, representing the original stock of the Modern Nile Cotton Company, Alexandria, Egypt. Each sample was divided into four sub- samples (200 grams each) and tested at four temperature degrees; i.e., $21^{\circ} \mathrm{C}$, $23^{\circ} \mathrm{C}, 25^{\circ} \mathrm{C}$ and $27^{\circ} \mathrm{C}$. All samples were preconditioned for 24 hours at least under the standard conditions of $65 \%$ $+2 \%$ relative humidity before testing. The fiber characters were tested using H.V.I. (High Volume Instrument) Spectrum II according to the U.S.D.A. standers at the testing laboratory of the Cotton Arbitration \& Testing General Organization (CATGO), Alexandria, Egypt.

\section{The characters studied were:}

1. Micronaire reading.

2. Maturity index.

3. Fiber upper half mean length (U.H.M.L.) (mm.).

4. Length uniformity index $(\%)$.

5. Short fiber index $(\%)$

6. Fiber bundle strength $(\mathrm{g} / \mathrm{tex})$.

7. Fiber elongation (\%).

8. Fiber brightness or reflectance degree (Rd \%).

9. Chroma or degree of yellowness $(+b)$.

10. Trash count.

11. Trash area (\%).

12. Spinning consistency index (SCI).

\section{Statistical procedures:}

Completely randomized design with three repetitions was used to outline this work. The attained data were statistically analyzed as a factorial experiment according to the procedure of Snedecor \& Cochran (1967). The least significant difference (L.S.D.) was calculated at 0.05 degree of probability to estimate the significant differences among means of the studied treatments.

\section{RESULTS AND DISCUSSION}

\section{H.V.I. Fiber characteristics:}

Data presented in Tables (1a and $1 \mathrm{~b}$ ) showed the mean values of the H.V.I. fiber properties. The attained results of the fiber properties for the two cotton cultivars used in this investigation will be presented and discussed herein in four sub-categories as follows:

\section{Effect of cotton variety on H.V.I. fiber properties:}

Results attained indicated that the effect of the cotton variety was significant on upper half mean length (U.H.M.L.), length uniformity index (U.I.), short fiber index (\%), fiber bundle strength, maturity index, micronaire reading, fiber reflectance degree ( $\mathrm{Rd} \%)$ yellowness degree $(+b)$ and trash area $(\%)$. While, the spinning consistency index (SCI), fiber elongation (\%) and trash count properties insignificantly affected by cotton varieties as shown in Tables (1a and $1 \mathrm{~b}$ ).

Furthermore, the highest mean values for length uniformity index (U.I.) (86.69 \%), short fiber index (6.12\%), fiber bundle strength (40.96 g/tex), maturity index (0.859) and micronaire reading (3.75 unit) were recorded for the cotton variety (Giza 86). While, the lowest mean values $(86.34 \%, 5.98 \%, 38.92 \mathrm{~g} / \mathrm{tex}, 0.85$ and 3.58 unit) of the aforementioned traits, respectively, were recorded for the cotton variety (Giza 94).

Giza 94 cotton variety also recorded the highest mean values for upper half mean length $(33.39 \mathrm{~mm})$, fiber reflectance degree $(76.85 \%)$, yellowness degree, $(9.21)$ and trash area $(0.94 \%)$. Whereas, the lowest mean values (32.78 mm, $76.09 \%, 9.03$ and $0.74 \%$ ) for the same traits, respectively, were attained from Giza 86 cotton variety.

These results could be explained on the base of the genetic differences between Giza 86 and Giza 94 cotton varieties.

In this connection, similar results were attained by Nomeir et al. (1990), who mention that the important physical properties of cotton fiber such as fiber length, fineness, maturity and strength vary considerably depending on the variety of cotton. Wali, (2003), Fouda (2004) and El-Banna (2013) found that there was highly significant difference in the upper half mean length and length uniformity index among the studied varieties. Also, Etman, (2010) indicated that the physical properties of the cotton fiber significantly differed depending on the genetic structure of the cultivar.

These results confirmed the findings obtained by Beheary (2001), who stated that, fiber maturity and bundle strength are varietal characteristics, basically, affected by the cotton genome. Yehia (2003), Hassan and Sanad (2006) and Osman (2007), mention that there were highly significant differences among studied cotton varieties in fiber strength and length.

\section{Effect of lint cotton grade on H.V.I. fiber properties:}

Data tabulated in Tables (1a and $1 \mathrm{~b}$ ) indicated that lint cotton grade had significant effect on the studied H.V.I. fibers properties, except fiber elongation.

The highest lint cotton grade i.e., good to fully good (G/FG) recorded the highest mean values $(87.13 \%, 41.33$ $\mathrm{g} / \mathrm{tex}, 0.87,4.20$ unit and $78.86 \%$ ) for length uniformity index, fiber bundle strength, maturity index, 
Table 1 a. Mean values of the H.V.I. fiber properties as affected by cotton varieties (A), lint cotton grades (B), temperature degrees $(C)$ and their interactions

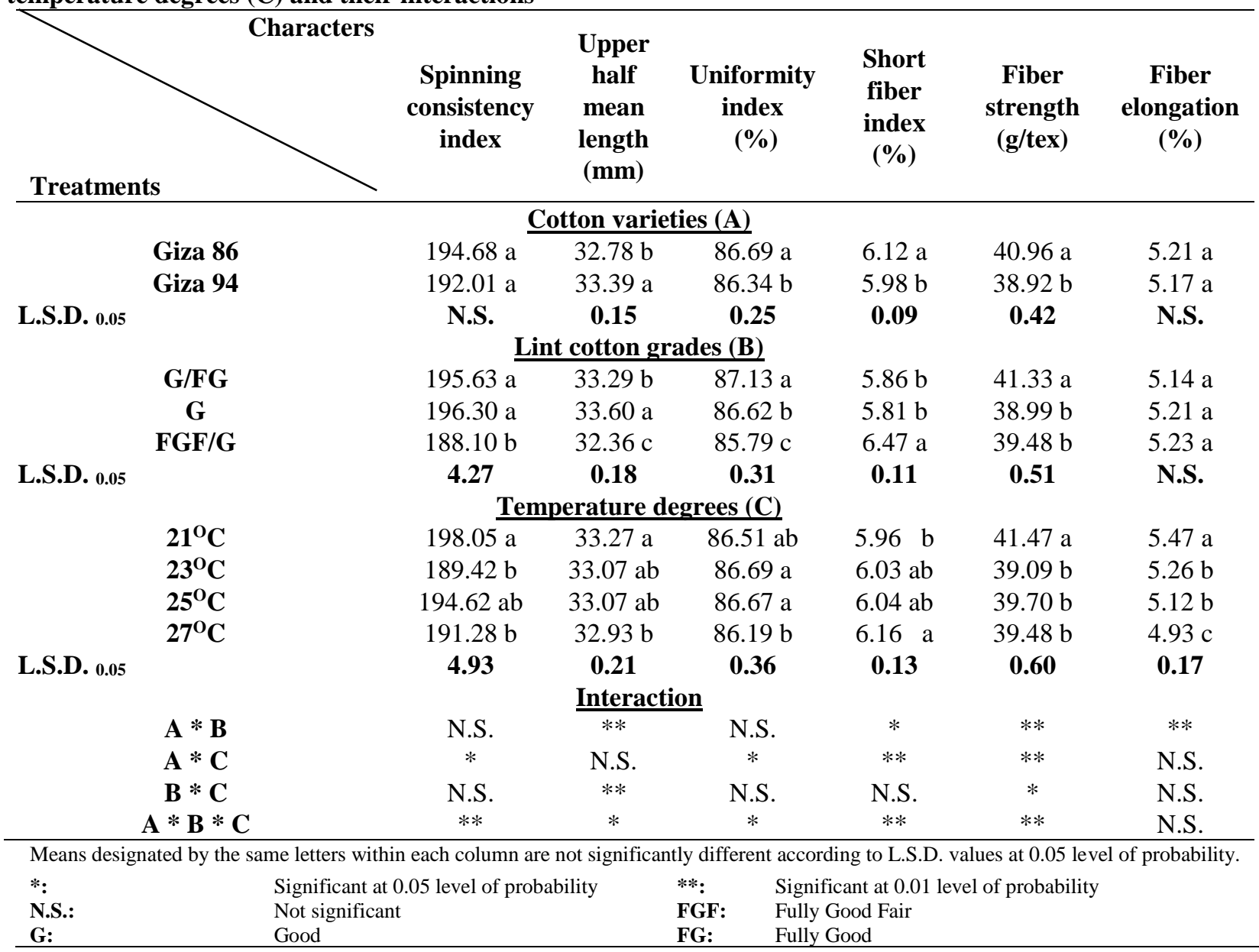

micronaire reading and fiber reflectance degree $(\mathrm{Rd} \%)$, respectively, and gave the lowest mean values $(8.98$, 21.61 and $0.24 \%)$ for the yellowness degree $(+b)$, trash count and trash area $(\%)$, respectively. On the other hand, the lowest lint cotton grade i.e., fully good fair to good (FGF/G) possessed the smallest mean values of the spinning consistency index (188.10), upper half mean length $(32.36 \mathrm{~mm}$.) length uniformity index $(85.79 \%)$ and fiber reflectance degree $(73.63 \%)$, but recorded the highest mean values $(6.47 \%, 82.19$ and $1.40 \%)$ for short fiber index, trash count and trash area (\%), respectively.

These results were expended and could be attributed to that the highest lint cotton grade always contains the highest numbers of mature fibers. Likewise, the trash properties gradually decreased as the lint cotton grade increased among all studied cotton varieties.

It is worth to mention that the medium lint cotton grade good $(\mathrm{G})$ recorded the highest mean values $(196.30,33.60 \mathrm{~mm}$. and 9.29) for the spinning consistency index, upper half mean length and degree of yellowness $(+b)$, respectively, as well as, the lowest mean values for short fiber index, $(5.81 \%)$, fiber bundle strength (38.99 g/tex), maturity index (0.84), and micronaire reading (3.33 unit).

Generally, the important physical properties of cotton fiber such as fiber length, fineness, maturity and strength were varied considerably depending on the cotton variety and lint cotton grade.

These results could be explained on the bases that the grade determined according to three factors color, trash and preparation.

These results agreed with those obtained by, Ibrahim (2010), Solieman (2016), who noticed that the better grades had longer fibers, more mature fiber, higher fiber bundle strength and less short fiber content. 
Table 1 b.Mean values of the H.V.I. fiber properties as affected by cotton varieties (A), lint cotton grades (B), temperature degrees $(C)$ and their interactions

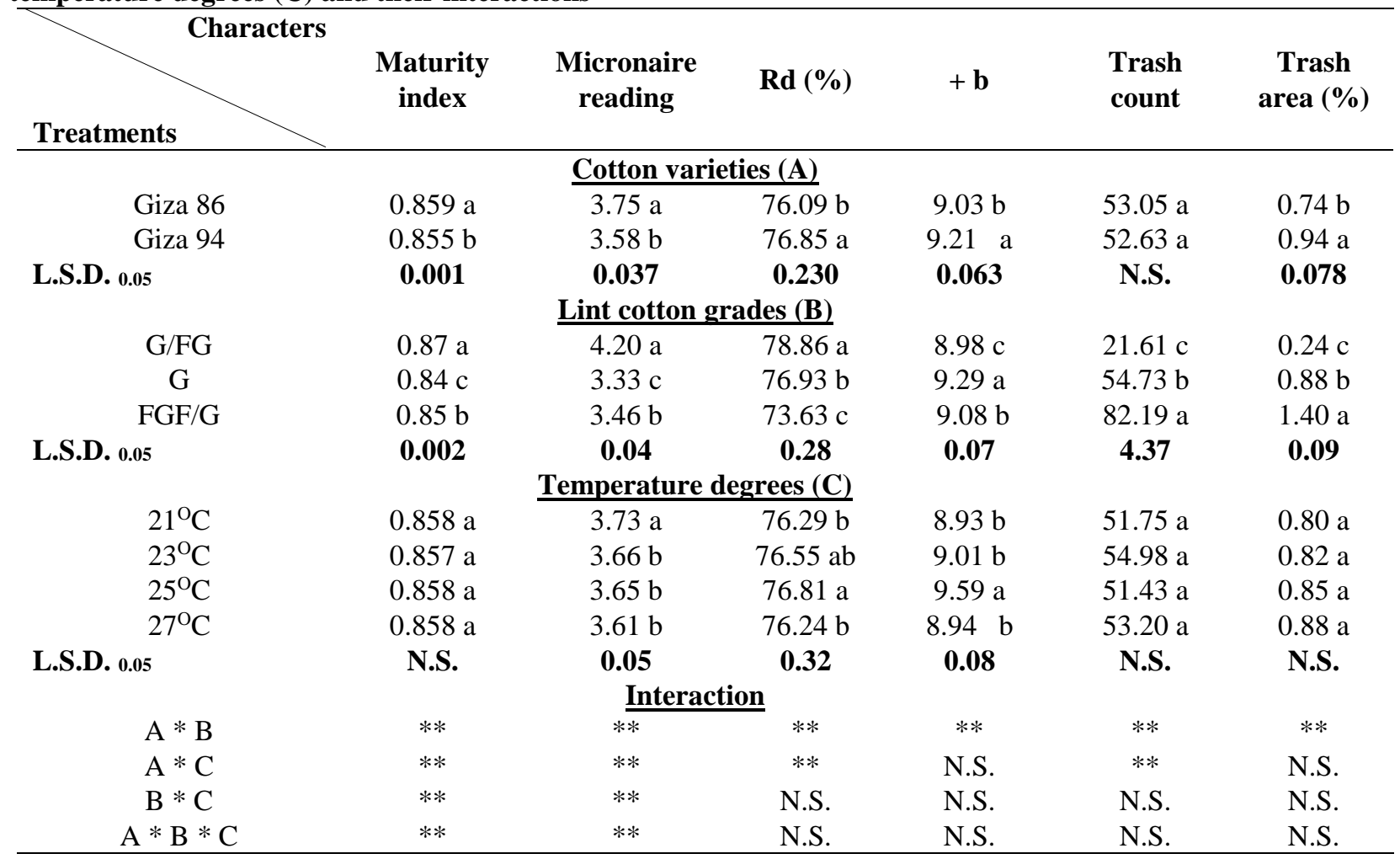

Means designated by the same letters within each column are not significantly different according to L.S.D. values at 0.05 level of probability.

$\begin{array}{llll}* *: & \text { Significant at } 0.01 \text { level of probability } & \text { N.S.: } & \text { Not significant } \\ \text { G: } & \text { Good } & \text { Rd: } & \text { Reflectance degree } \\ \text { FG: } & \text { Fully Good } & \text { +b: } & \text { Yellowness degree } \\ \text { FGF: } & \text { Fully Good Fair } & & \end{array}$

\section{Effect of conditioning temperature on H.V.I. fiber properties:}

Regarding Tables ( $1 \mathrm{a}$ and $1 \mathrm{~b}$ ), it is obvious that the conditioning temperature degrees had a significant effect on the spinning consistency index, upper half mean length, length uniformity index, short fiber index, fiber bundle strength, fiber elongation (\%), micronaire reading, fiber reflectance degree and yellowness degree. On the contrary, fiber maturity index, trash count and trash area were insignificantly affected due to the conditioning temperature.

The highest mean values of the spinning consistency index (198.05), upper half mean length $(33.27 \mathrm{~mm})$, fiber bundle strength (41.47 g/tex), fiber elongation (5.47\%) and micronaire reading (3.73 unit), were recorded using the conditioning temperature degree of $21^{\circ} \mathrm{C}$. While, the lowest values of upper half mean length (32.93. mm), uniformity index $(86.19 \%)$, fiber bundle strength (39.48 $\mathrm{g} / \mathrm{tex}$ ), fiber elongation (4.93\%), micronaire reading (3.61 unit), reflectance degree ( $\mathrm{Rd} \%)(76.24 \%)$ and yellowness degree $(+b)(8.94)$ were recorded using the conditioning temperature degree of $27^{\circ} \mathrm{C}$, as shown in Tables ( $1 \mathrm{a}$ and $1 \mathrm{~b}$ ).

The conditioning temperature degrees $23^{\circ} \mathrm{C}, 25^{\circ} \mathrm{C}$ and $27^{\circ} \mathrm{C}$ gave the highest mean values for length uniformity index, $(86.69 \%$ and $86.67 \%)$ and short fiber index, $(6.16 \%)$, respectively. Whereas, the lowest mean value $(5.96 \%)$ for short fiber index was attained from the conditioning temperature degrees $21^{\circ} \mathrm{C}$, as shown in Table (1a) .

The highest mean values of reflectance degree and yellowness degree, (76.81\% and 9.59) were gained using the conditioning temperature degree $25^{\circ} \mathrm{C}$. Meanwhile, the lowest mean values (76.24\% and $76.29 \%)$ for ( $\mathrm{Rd} \%)$ and $(8.93,9.01$ and 8.94$)$ for $(+b)$ were reached using the temperature degrees $27^{\circ} \mathrm{C}$ and $21^{\circ} \mathrm{C}$ for $(\mathrm{Rd} \%)$, and 
$\left(21^{\circ} \mathrm{C}, 23^{\circ} \mathrm{C}\right.$ and $\left.27^{\circ} \mathrm{C}\right)$ for $(+b)$, respectively, as shown in Table ( $1 \mathrm{~b})$.

In conclusion, increasing conditioning temperature degree up to $27^{\circ} \mathrm{C}$ increased the short fiber index (\%) and decreased the upper half mean length, length uniformity index $(\%)$ and fiber elongation (\%).

\section{Interactions between variety, grade and temperature} (A x B x C):

Tables $(1 \mathrm{a}$ and $1 \mathrm{~b})$, cleared the first $(\mathrm{A} \times \mathrm{B}),(\mathrm{A} \times$ $\mathrm{C}),(\mathrm{B} \times \mathrm{C})$ and the second order interactions $(\mathrm{A} \times \mathrm{B} \times$ C) of the three studied factors i.e. cotton variety (A), lint grade (B) and temperature degree (C) had significant effect on many studied traits. That means that each factor behaved in different way by changing the other two factors. Meanwhile, the remaining interactions were not significant which indicated that each factor acted as an independent factor.

Concerning $(\mathrm{A} \times \mathrm{B})$ interaction, it could be noticed that the highest mean values for upper half mean length $(33.84 \mathrm{~mm}$ ) was recorded from the grade $\mathrm{G} / \mathrm{FG}$ of Giza 94, short fiber index $(6.53 \%)$ was attained from FGF/G of Giza 86, fiber strength (42.91 g/tex) was ginned from G/FG of Giza 86, fiber elongation (5.32 \%) was noticed from $\mathrm{G} / \mathrm{FG}$ of Giza 86, fiber maturity index (0.87), micronaire reading (4.26), $\mathrm{Rd}(79.78 \%)$ were possessed by G/FG of Giza 94 and $+b 9.45$ was recorded from $\mathrm{G}$ of Giza 94. Also, the highest trash count (89.00) and trash area $(1.63 \%)$ were realized from FGF/G of Giza 94 . On the other hand, the lowest mean values for upper half mean length $(32.06 \mathrm{~mm})$ and $+\mathrm{b}(8.97)$ were attained from the grade FGF/G of Giza 86 and short fiber index $(5.71 \%)$, fiber elongation (4.96\%), trash count (18.00) and trash area $(0.18 \%)$ were recorded from the grade G/FG of Giza 94. Likewise, the lowest mean values for fiber strength (37.93 g/tex), fiber maturity index (0.84), micronaire reading (3.21) and $\mathrm{Rd}(73.29 \%)$ were recorded from interaction between Giza 94 with the lowest lint cotton grade FGF/G, as shown in Table (2).

With respect to the interaction between cotton variety and conditioning temperature degree $(\mathrm{A} \times \mathrm{C})$, it could be concluded that the highest mean values of spinning consistency index (201.83) was recorded from Giza 86 using $21^{\circ} \mathrm{C}$, uniformity index $(87.09 \%)$ was recorded from Giza 86 using $23^{\circ} \mathrm{C}$, short fiber index $(6.36 \%)$ was attained from Giza 86 using $27^{\circ} \mathrm{C}$, fiber strength (43.06 $\mathrm{g} /$ tex), fiber maturity index (0.862), micronaire reading (3.87) were attained from Giza 86 using $21^{\circ} \mathrm{C}$, and high $\mathrm{Rd}(77.17 \%)$ was found from Giza 94 using $23^{\circ} \mathrm{C}$, also the highest trash count $(59.40 \%)$ was reached from Giza 86 using $23^{\circ} \mathrm{C}$. On the other side, the lowest mean values of spinning consistency index (188.90) was recorded from Giza 86 using $23^{\circ} \mathrm{C}$, uniformity index $(86.03 \%)$ was recorded from Giza 86 using $27^{\circ} \mathrm{C}$, short fiber index $(5.95 \%)$ was recorded from Giza 94 with $21^{\circ} \mathrm{C}$, fiber strength $(38.10 \mathrm{~g} /$ tex $)$, fiber maturity index (0.853), micronaire reading (3.52) were reached from Giza 94 with $23^{\circ} \mathrm{C}$, also the lowest $\mathrm{Rd}(75.69 \%)$ resulted from Giza 86 at $27^{\circ} \mathrm{C}$ and lowest trash count $(47.40 \%)$ realized from conditioning Giza 86 fibers at $21^{\circ} \mathrm{C}$, as shown in Table (3).

Table 2. The first order interaction between cotton varieties and lint cotton grades (A $x$ B) for the H.V.I. fiber properties

\begin{tabular}{|c|c|c|c|c|c|c|c|c|c|c|c|}
\hline \multicolumn{2}{|c|}{ Variables } & \multirow[b]{2}{*}{$\begin{array}{c}\text { Upper } \\
\text { half } \\
\text { mean } \\
\text { length } \\
(\mathbf{m m})\end{array}$} & \multirow[b]{2}{*}{$\begin{array}{c}\text { Short } \\
\text { fiber } \\
\text { index } \\
(\%)\end{array}$} & \multirow[b]{2}{*}{$\begin{array}{c}\text { Fiber } \\
\text { strength } \\
(\mathrm{g} / \mathrm{tex})\end{array}$} & \multirow[b]{2}{*}{$\begin{array}{c}\text { Fiber } \\
\text { elongation } \\
(\%)\end{array}$} & \multirow[b]{2}{*}{$\begin{array}{c}\text { Maturity } \\
\text { index }\end{array}$} & \multirow[b]{2}{*}{$\begin{array}{l}\text { Micronaire } \\
\text { reading }\end{array}$} & \multirow[b]{2}{*}{$\begin{array}{l}\text { Rd } \\
(\%)\end{array}$} & \multirow[b]{2}{*}{$+b$} & \multirow[b]{2}{*}{$\begin{array}{l}\text { Trash } \\
\text { count }\end{array}$} & \multirow[b]{2}{*}{$\begin{array}{c}\text { Trash } \\
\text { area } \\
(\%)\end{array}$} \\
\hline $\begin{array}{l}\text { Cotton } \\
\text { varieties } \\
\text { (A) }\end{array}$ & $\begin{array}{c}\text { Lint } \\
\text { cotton } \\
\text { grades } \\
\text { (B) }\end{array}$ & & & & & & & & & & \\
\hline \multirow{3}{*}{ Giza 86} & G/FG & 32.75 & 6.01 & 42.91 & 5.32 & 0.86 & 4.14 & 77.93 & 8.98 & 25.23 & 0.30 \\
\hline & G & 33.53 & 5.82 & 38.93 & 5.12 & 0.85 & 3.41 & 76.41 & 9.14 & 58.55 & 0.75 \\
\hline & FGF/G & 32.06 & 6.53 & 41.03 & 5.19 & 0.85 & 3.70 & 73.96 & 8.97 & 75.38 & 1.18 \\
\hline \multirow{3}{*}{ Giza 94} & G/FG & 33.84 & 5.71 & 39.76 & 4.96 & 0.87 & 4.26 & 79.78 & 8.99 & $\ \wedge .00$ & 0.18 \\
\hline & G & 33.67 & 5.80 & 39.06 & 5.29 & 0.84 & 3.26 & 77.45 & 9.45 & 50.90 & 1.00 \\
\hline & FGF/G & 32.65 & 6.42 & 37.93 & 5.26 & 0.84 & 3.21 & 73.29 & 9.19 & 89.00 & 1.63 \\
\hline \multicolumn{2}{|c|}{ L.S. D 0.05} & 0.26 & 0.15 & 0.73 & 0.21 & 0.002 & 0.06 & 0.39 & 0.10 & 6.19 & 0.13 \\
\hline
\end{tabular}

G:

FG:

FGF:
Good

Fully Good

Fully Good Fair
Rd: $\quad$ Reflectance degree

+b: Yellowness degree 
Table 3. The first order interaction between cotton varieties and temperature degrees (A x C) for the H.V.I. fiber properties

\begin{tabular}{|c|c|c|c|c|c|c|c|c|c|}
\hline \multicolumn{2}{|c|}{ Variables } & \multirow[b]{2}{*}{$\begin{array}{l}\text { Spinning } \\
\text { consistency } \\
\text { index }\end{array}$} & \multirow[b]{2}{*}{$\begin{array}{c}\text { Uniformity } \\
\text { index } \\
(\%)\end{array}$} & \multirow{2}{*}{$\begin{array}{c}\text { Short } \\
\text { fiber } \\
\text { index } \\
(\%)\end{array}$} & \multirow[b]{2}{*}{$\begin{array}{c}\text { Fiber } \\
\text { strength } \\
(\mathrm{g} / \mathrm{tex})\end{array}$} & \multirow[b]{2}{*}{$\begin{array}{l}\text { Maturity } \\
\text { index }\end{array}$} & \multirow[b]{2}{*}{$\begin{array}{l}\text { Micronaire } \\
\text { reading }\end{array}$} & \multirow[b]{2}{*}{$\begin{array}{l}\text { Rd } \\
(\%)\end{array}$} & \multirow[b]{2}{*}{$\begin{array}{l}\text { Trash } \\
\text { count }\end{array}$} \\
\hline $\begin{array}{l}\text { Cotton } \\
\text { varieties } \\
\text { (A) } \\
\end{array}$ & $\begin{array}{c}\text { Temperature } \\
\text { degrees }(\mathrm{C})\end{array}$ & & & & & & & & \\
\hline \multirow{4}{*}{ Giza 86} & $21^{\circ} \mathrm{C}$ & 201.83 & 86.76 & 5.96 & 43.06 & 0.862 & 3.87 & 76.23 & 47.40 \\
\hline & ${ }^{23^{\circ}} \mathrm{C}$ & 188.90 & 87.09 & 6.03 & 40.08 & 0.861 & 3.81 & 75.93 & 59.40 \\
\hline & ${ }^{25^{\circ}} \mathrm{C}$ & 198.47 & 86.87 & 6.12 & 41.01 & 0.859 & 3.67 & 76.55 & 51.47 \\
\hline & ${ }^{27^{\circ} \mathrm{C}}$ & 189.50 & 86.03 & 6.36 & 39.67 & 0.858 & 3.66 & 75.69 & 53.93 \\
\hline \multirow{4}{*}{ Giza 94} & ${ }^{21^{\circ}} \mathrm{C}$ & 194.27 & 86.26 & 5.95 & 39.88 & 0.855 & 3.58 & 76.36 & 56.10 \\
\hline & ${ }^{23^{\circ}} \mathrm{C}$ & 189.93 & 86.28 & 6.04 & 38.10 & 0.853 & 3.52 & 77.17 & 50.57 \\
\hline & ${ }^{25^{\circ}} \mathrm{C}$ & 190.77 & 86.46 & 5.96 & 38.39 & 0.858 & 3.63 & 77.06 & 51.40 \\
\hline & ${ }^{27^{\circ} \mathrm{C}}$ & 193.07 & 86.36 & 5.96 & 39.29 & 0.858 & 3.56 & 76.79 & 52.47 \\
\hline \multicolumn{2}{|c|}{ L.S. D0.05 } & 6.97 & 0.51 & 0.18 & 0.84 & 0.003 & 0.07 & 0.46 & 7.15 \\
\hline
\end{tabular}

Regarding $(\mathrm{B} \times \mathrm{C})$ interaction effect, could be summarized as follows: the highest upper half mean length $(33.91 \mathrm{~mm})$ was reached when lint cotton grade good $(\mathrm{G})$ was tested at $25^{\circ} \mathrm{C}$. In the same context the highest fiber bundle strength (42.45 g/tex), maturity index (0.875), micronaire reading (4.33) were recorded when high lint cotton grade $(\mathrm{G} / \mathrm{FG})$ was tested at $21^{\circ} \mathrm{C}$. Conversely, the lowest upper half mean length resulted from conditioning lint cotton grade $(\mathrm{FGF} / \mathrm{G})$ at any temperature ranged from 21 to $27^{\circ} \mathrm{C}$, as well as the lowest fiber bundle strength ( $38.17 \mathrm{~g} / \mathrm{tex})$, fiber maturity index (0.848) and micronaire reading (3.29) were recorded by using the lint cotton grade (Good) at the conditioning temperature degrees $27^{\circ} \mathrm{C}$ and $23^{\circ} \mathrm{C}$, respectively, as shown in Table (4).

Table 4. The first order interaction between lint cotton grades and temperature degrees (B x C) for the H.V.I. fiber properties

\begin{tabular}{|c|c|c|c|c|c|}
\hline \multicolumn{2}{|c|}{ Variables } & \multirow{2}{*}{$\begin{array}{c}\text { Upper half } \\
\text { mean length } \\
(\mathrm{mm})\end{array}$} & \multirow{2}{*}{$\begin{array}{l}\text { Fiber strength } \\
\qquad(\mathrm{g} / \mathrm{tex})\end{array}$} & \multirow[b]{2}{*}{ Maturity index } & \multirow{2}{*}{$\begin{array}{l}\text { Micronaire } \\
\text { reading }\end{array}$} \\
\hline $\begin{array}{l}\text { Lint cotton } \\
\text { grades }(B)\end{array}$ & $\begin{array}{c}\text { Temperature } \\
\text { degrees }(\mathrm{C})\end{array}$ & & & & \\
\hline \multirow{5}{*}{ G/FG } & $21^{\circ} \mathrm{C}$ & 33.56 & 42.45 & 0.875 & 4.33 \\
\hline & $2^{\circ} \mathrm{C}$ & 33.55 & 40.39 & 0.874 & 4.33 \\
\hline & ${ }^{2} 5^{\circ} \mathrm{C}$ & 32.94 & 40.76 & 0.867 & 4.02 \\
\hline & $27^{\circ} \mathrm{C}$ & 33.14 & 41.73 & 0.872 & 4.12 \\
\hline & $21^{\circ} \mathrm{C}$ & 33.70 & 40.83 & 0.849 & 3.36 \\
\hline \multirow{3}{*}{ Good } & $23^{\circ} \mathrm{C}$ & 33.38 & 38.40 & 0.848 & 3.29 \\
\hline & ${ }^{25^{\circ}} \mathrm{C}$ & 33.91 & 38.58 & 0.851 & 3.35 \\
\hline & $27^{\circ} \mathrm{C}$ & 33.41 & 38.17 & 0.850 & 3.34 \\
\hline \multirow{4}{*}{ FGF/G } & $21^{\circ} \mathrm{C}$ & 32.54 & 41.13 & 0.852 & 3.49 \\
\hline & ${ }^{23^{\circ}} \mathrm{C}$ & 32.28 & 38.48 & 0.849 & 3.37 \\
\hline & $25^{\circ} \mathrm{C}$ & 32.37 & 39.77 & 0.857 & 3.59 \\
\hline & $27^{\circ} \mathrm{C}$ & 32.24 & 38.55 & 0.852 & 3.37 \\
\hline \multicolumn{2}{|c|}{ L.S. $D_{0.05}$} & 0.37 & 1.03 & 0.003 & 0.08 \\
\hline
\end{tabular}

The second order interaction $(\mathrm{A} \times \mathrm{B} \times \mathrm{C})$ cleared that the highest spinning consistency index (204.40), uniformity index $(87.45 \%)$, fiber bundle strength (44.13 gltex) and maturity index (0.876) were attained from high lint cotton grade (G/FG) of Giza 86 cultivar conditioned at $21^{\circ} \mathrm{C}$. The highest upper half mean length $(34.08 \mathrm{~mm})$ was recorded from high lint cotton grade $(\mathrm{G} / \mathrm{FG})$ of cotton variety Giza 94 that conditioned at $21^{\circ} \mathrm{C}$, the highest short fiber index (7.07\%) was attained from lint cotton grade (FGF/G) of cotton variety Giza 86 conditioned at $27^{\circ} \mathrm{C}$ and the highest micronaire reading (4.42) was recorded from high lint cotton grade (G/FG) of Giza 86 cotton variety conditioned at $23^{\circ} \mathrm{C}$.
D0.05 
Table 5. The second order interaction between cotton varieties, lint cotton grades and temperature degrees (A x B x C) for the H.V.I. fiber properties

\begin{tabular}{|c|c|c|c|c|c|c|c|c|c|}
\hline \multicolumn{3}{|c|}{ Variables } & \multirow[b]{2}{*}{$\begin{array}{c}\text { Spinning } \\
\text { consistency } \\
\text { index }\end{array}$} & \multirow{2}{*}{$\begin{array}{c}\text { Upper } \\
\text { half } \\
\text { mean } \\
\text { length } \\
(\mathrm{mm})\end{array}$} & \multirow[b]{2}{*}{$\begin{array}{c}\text { Uniformity } \\
\text { index }(\%)\end{array}$} & \multirow[b]{2}{*}{$\begin{array}{c}\text { Short } \\
\text { fiber } \\
\text { index } \\
(\%)\end{array}$} & \multirow[b]{2}{*}{$\begin{array}{c}\text { Fiber } \\
\text { strength } \\
\text { (g/tex) }\end{array}$} & \multirow[b]{2}{*}{$\begin{array}{c}\text { Maturity } \\
\text { index }\end{array}$} & \multirow[b]{2}{*}{$\begin{array}{c}\text { Micronaire } \\
\text { reading }\end{array}$} \\
\hline $\begin{array}{l}\text { Cotton } \\
\text { varieties } \\
\text { (A) }\end{array}$ & $\begin{array}{c}\text { Lint } \\
\text { grades } \\
\text { (B) }\end{array}$ & $\begin{array}{c}\text { Temperature } \\
\text { degrees } \\
\text { (C) }\end{array}$ & & & & & & & \\
\hline \multirow{11}{*}{ Giza 86} & \multirow{4}{*}{ G/FG } & $21^{\mathrm{O}} \mathrm{C}$ & 204.40 & 33.04 & 87.45 & 5.83 & 44.13 & 0.876 & 4.39 \\
\hline & & $23^{\circ} \mathrm{C}$ & 177.40 & 33.15 & 87.30 & 5.90 & 41.52 & 0.876 & 4.42 \\
\hline & & $25^{\circ} \mathrm{C}$ & 203.10 & 32.06 & 86.97 & 6.29 & 42.69 & 0.859 & 3.73 \\
\hline & & $27^{\circ} \mathrm{C}$ & 202.70 & 32.75 & 86.93 & 6.02 & 43.30 & 0.868 & 4.02 \\
\hline & \multirow{4}{*}{ Good } & $21^{\circ} \mathrm{C}$ & 199.40 & 33.52 & 86.43 & 5.84 & 40.87 & 0.850 & 3.42 \\
\hline & & $23^{\circ} \mathrm{C}$ & 197.90 & 33.43 & 87.44 & 5.78 & 38.65 & 0.852 & 3.42 \\
\hline & & $25^{\circ} \mathrm{C}$ & 198.90 & 33.96 & 87.31 & 5.64 & 38.67 & 0.851 & 3.39 \\
\hline & & $27^{\circ} \mathrm{C}$ & 188.70 & 33.22 & 86.41 & 6.00 & 37.53 & 0.851 & 3.40 \\
\hline & \multirow{4}{*}{ FGF/G } & $21^{\circ} \mathrm{C}$ & 201.70 & 32.33 & 86.39 & 6.21 & 40.17 & 0.859 & 3.79 \\
\hline & & $23^{\mathrm{O}} \mathrm{C}$ & 191.40 & 32.07 & 86.53 & 6.41 & 40.08 & 0.855 & 3.57 \\
\hline & & $25^{\circ} \mathrm{C}$ & 193.40 & 32.21 & 86.35 & 6.44 & 41.68 & 0.866 & 3.89 \\
\hline \multirow{14}{*}{ Giza 94} & & $27^{\circ} \mathrm{C}$ & 177.10 & 31.64 & 84.75 & 7.07 & 38.17 & 0.855 & 3.55 \\
\hline & \multirow{4}{*}{ G/FG } & $21^{\mathrm{O}} \mathrm{C}$ & 196.90 & 34.08 & 86.98 & 5.46 & 40.77 & 0.873 & 4.26 \\
\hline & & $23^{\circ} \mathrm{C}$ & 193.60 & 33.95 & 87.15 & 5.70 & 39.27 & 0.871 & 4.25 \\
\hline & & $25^{\circ} \mathrm{C}$ & 191.90 & 33.82 & 87.23 & 5.73 & 38.83 & 0.875 & 4.31 \\
\hline & & $27^{\circ} \mathrm{C}$ & 195.00 & 33.52 & 87.04 & 5.77 & 40.15 & 0.876 & 4.22 \\
\hline & \multirow{4}{*}{ Good } & $21^{\circ} \mathrm{C}$ & 202.30 & 33.88 & 86.62 & 5.73 & 40.79 & 0.848 & 3.29 \\
\hline & & $23^{\circ} \mathrm{C}$ & 194.20 & 33.32 & 86.26 & 5.93 & 38.15 & 0.845 & 3.16 \\
\hline & & $25^{\circ} \mathrm{C}$ & 195.30 & 33.86 & 86.47 & 5.71 & 38.49 & 0.850 & 3.31 \\
\hline & & $27^{\circ} \mathrm{C}$ & 193.70 & 33.61 & 86.00 & 5.84 & 38.81 & 0.849 & 3.28 \\
\hline & \multirow{4}{*}{ FGF/G } & $21^{\circ} \mathrm{C}$ & 183.60 & 32.75 & 85.19 & 6.49 & 38.08 & 0.844 & 3.19 \\
\hline & & $23^{\mathrm{O}} \mathrm{C}$ & 182.00 & 32.49 & 85.44 & 6.48 & 36.88 & 0.843 & 3.17 \\
\hline & & $25^{\circ} \mathrm{C}$ & 185.10 & 32.52 & 85.68 & 6.43 & 37.85 & 0.848 & 3.28 \\
\hline & & $27^{\circ} \mathrm{C}$ & 190.50 & 32.84 & 86.04 & 6.26 & 38.92 & 0.848 & 3.19 \\
\hline & \multicolumn{2}{|c|}{ L.S. D $_{0.05}$} & 12.08 & 0.53 & 0.89 & 0.32 & 1.47 & 0.005 & 0.13 \\
\hline
\end{tabular}

Conversely, the lowest spinning consistency index (177.10), fiber length $(31.64 \mathrm{~mm})$ and uniformity index $(84.75 \%)$ were recorded from the lowest lint cotton grade $(\mathrm{FGF} / \mathrm{G})$ of the cotton variety Giza 86 conditioned at $27^{\circ} \mathrm{C}$, whereas, the lowest fiber strength $(36.88 \mathrm{~g} / \mathrm{tex})$ and maturity index $(0.843)$ were recorded from grade $(\mathrm{FGF} / \mathrm{G})$ of Giza 94 cotton variety conditioned at $23^{\circ} \mathrm{C}$, the lowest short fiber index (5.46\%) was attained from lint cotton grade $(\mathrm{G} / \mathrm{FG})$ of the cotton variety Giza 94 at $21^{\circ} \mathrm{C}$ and micronaire reading (3.16) was recorded from lint cotton grade $(\mathrm{G})$ of the cotton variety Giza 94 at $23^{\circ} \mathrm{C}$, as shown in Table (5).

\section{CONCLUSION}

Generally, it could be concluded that the best fiber quality over all studied cotton varieties and grades were achieved at the conditioning temperature of $21^{\circ} \mathrm{C}$ and this was recommended by the ASTM.

\section{REFERENCES}

ASTM D-1776-15 2015. Practice for conditioning and testing textiles. ASTM International, West Conshohocken, PA, www.astm.org

Beheary, M.G.I. 2001. Single yarn strength as affected by cotton fiber maturity parameters. J. Adv. Agric. Res., 6 (3): $575-583$.

CoStat 6.311, C. C. W. 1998-2005. Cohort software798light house Ave. PMB320, Monterey, CA93940, and USA.email:info@cohort.com. http://www.cohort.com/DownloadCoStatPart2.html .

El-Banna, A.A.A.E. 2013. The use of artificial neural network for the spinnability predication of the Egyptian cotton. Ph.D. Thesis, Fac. Agric., Saba Basha, Alex. Univ., Egypt

Etman, A. Hanan 2010. Impact of color and length distributions on the fiber mechanical properties of some Egyptian cotton hybrids. M.Sc. Thesis, Fac. Agric., Saba Basha, Alex. Univ., Egypt 
Fouda, H.S. 2004. A study on fiber quality index of some Egyptian cotton varieties. M.Sc. thesis, Fac. Agric., Saba Basha, Alex. Univ., Egypt

Hassan, I.S.M. and Sanad Suzan H. 2006. Effect of different environments on yield, yield components, fiber and open-end yam quality properties of some Egyptian long staple cotton genotypes. Egypt. J. Agric. Res., 84(6): 1887- 1905.

Ibrahim, A. E. I. 2010. Impact of roller gin type and seed-cotton levels on ginning efficiency and fiber properties. Alex. J. Agric. Res., 55 (1): 13-19.

Liakatas A, D. Roussopoulos and W.J. Whittington 1998. Controlled-temperature effects on cotton yield and fiber properties. J. Agric. Sci., 463-471.

Nomeir, A. A., M. M. Syaim, Ahmed Nafisa, T. and M.A. Abdel- Mohsen. 1990. The potential spinning performance and yarn quality of commercial extra-long staple Egyptian cottons. Agric Res. Rev., 68 (6):1271 - 1286.

Osman, N.A.A. 2007. Arithmetic estimation of fiber maturity in the Egyptian cotton. M.Sc. Thesis, Fac. Agric., SabaBasha, Alex Univ., Egypt
Pettigrew, W.T. 2001. Environmental effects on cotton fiber carbohydrate concentration and quality. Crop Sci.; 41:1108-1113.

Richard, G.P., G.C. Roy and Z. Jinfa 2006. Genetic variation for agronomic and fiber properties in an introgressed recombinant inbred population of cotton. Crop Sci., 46:1311-1317.

Snedecor, G.W. and W.G. Cochran, 1967. Statistical Method. 6th ed. Iowa State Univ. Press, Ames, Iowa, USA.

Solieman, A. M. S. (2016). Impact of reciprocal position of the conventional roller gin stand fixed knife on ginning efficiency and cotton fiber properties. M.Sc. Thesis, Fac. Agric., Saba Basha, Alex. Univ., Egypt

Wali, Asal M. A. (2003). Effect of cotton fiber properties on yarn quality. M.Sc. thesis, Fac. Agric., Saba Basha, Alex. Univ., Egypt

Yehia, K.A.M. (2003). Studies on cotton fiber maturity. MSc. Thesis, Fac. Agric., Saba-Basha, Alex Univ. Egypt.

\section{الملخص العريب \\ إستجابة جودة الألياف لارجة الحرارة ورتبة القطن الثعر لصنفين من الأقطان طويلة التيلة \\ إبراهيم عباس السبد إبرهيم ، على أحمد على البنا}



، متانة الألياف (جم/تكس)، ونضج الألياف (\%) ، قراءة الميكرونير ودرجة انعكاس اللون Rd\% ، في حين سجَت نفس الرنبة أدنى القيم لمؤشر نسبة الألياف القصيرة (\%) ، ودرجة إصفرار اللون (b+) ، وعدد ومساحة الشوائب (\%). من جهه أخرى سجلت درجة حرارة تكيف العينة ( اب درجة مئوية) أعلى القيم لمتوسط طول التيلة (UHML)، مؤشر ثابت الغزل (S.C.I.) ، متانة الألياف (جم/تكس)، إستطالة الألياف

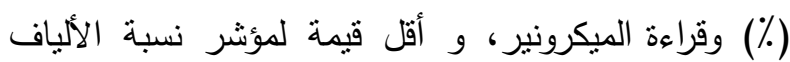

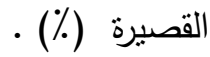

كذلك سجل صنف القطن جيزة 1 أعلى القيم لكلاً من معامل إنتظامية الألياف، ومعامل الثعبرات القصبيرة ، ومتانة ونضج الألياف ، وقراءة الميكرونير بالمقارنة بصنف القطن جيزة ؟ 9، وأفضل صفات جودة للألياف تحققت عند إستخدام حرارة تكييف اY درجة مئوية.
أجريت هذه الدراسة بقسم الإنتاج النباتي ، كلية الزراعة

(سابا باشا) ، جامعة الإسكندرية ، مصر ، خهلا موسم

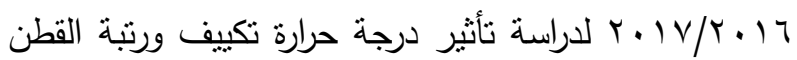
الشعر على خواص ألياف القطن لصنفين من القطن طويل التيلة ـ إستخدمت فى هذه الدراسة ثناث رثب من القطن الثعر وهى: جود/فولى جود، جود ، فولى جود فير/ جود، وصنفى من القطن المصرى طويل التيلة هما جيزة 1 1 ، وجيزة ؟9 9 وأربعة مستويات من درجات الحرارة اللازمة لتكييف عينات

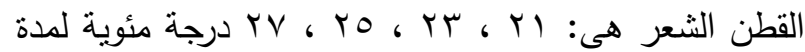
ع r ساعة قبل إجراء الإختبارات وتم اختبار صفات جودة الالياف باستخدام جهاز HVI طراز Spectrum II تحت جو

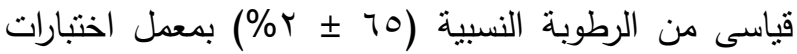
التيلة بالهيئة العامة للتحكيم واختبارات القطن - سموحة اسكندرية.

وأثنارت النتائج المتحصل عليها أن رتبة القطن جود/فولى جود تقوقت على رتب القطن الأخرى وأعطت أعلى القيم 